Original scientific paper

Received: 1 January 2018 / Accepted: 20 March 2018 UDC: 327.56(497.115); 327.56(497.6); 327(4-672EU)

DOI: 10.11643/issn.2217-995X172SPB92

\title{
(In)effective Planning Capacity of CSDP Missions: Comparative Analysis of EULEX Kosovo and EUFOR Althea ${ }^{1}$
}

\author{
IVANA BOŠTJANCIC PULKO* \\ Centre for European Perspective, Slovenia
}

\begin{abstract}
This paper evaluates the planning capacity of two Common Security and Defence (CSDP) missions (EULEX Kosovo and EUFOR Althea) in order to assess the effectiveness of CSDP planning process. Both missions suffer due to partial interests within the EU and low positioning of CSDP on political agendas of the member states. Compared to NATO, EU missions' political control is more much detailed once the mission is deployed. CSDP planning architecture has been considerably reformed since the inception of the first missions in 2003, however the supervision by the member states is still present in all phases of restructuring and implementation. EULEX planning process includes a well elaborated lessons learnt process, however the implementation of the findings on the operational level is rather weak whereas EUFOR Althea profited mostly from the access to NATO planning assets. CSDP missions are political missions and their effectiveness seems to be of secondary importance to the EU member states.
\end{abstract}

Keywords: Kosovo, Bosnia and Herzegovina, EU, CSDP missions, conflict prevention.

\section{Introduction}

This article touches upon EU's role in preventing further conflicts in the Western Balkans since the urgency of improving conflict preventive capabilities is of great importance for the EU. This article aims to answer whether EU's responses after the conflicts in Kosovo as well as in Bosnia and Herzegovina $(\mathrm{BiH})$ have been planned and are further executed in a meaningful way. Increased effectiveness and impact of EU external action were clearly recognized by the European Council, which committed to ,further improving the efficiency and effectiveness of the EU Comprehensive Approach, including as it applies to EU crisis management.' The assessment of the planning processes of the two CSDP mis-

1 "This work was supported by the European Union's Horizon 2020 Programme for Research and Innovation [Grant Agreement No 653371] for Project entitled: "Improving the Effectiveness of Capabilities in EU Conflict Prevention - IECEU". Three year project evaluated the effectiveness of 10 civilian and military CSDP missions in the Western Balkans, Africa, Middle East and Afghanistan. Formoreinformationabouttheprojectpleasesee: www.ieceu-project.com.

2 European Council 2013.

*ivana.bostjancic-pulko@cep.si 
sions (EULEX Kosovo and EUFOR Althea) proves that EU has difficulties in uniting their member states' positions related to the CSDP missions even in the region with a clear EU perspective, where their stabilisation interests are most vital. EU missions are never "lone wolf" actions but part of the EU's wider long-term policies and strategy towards a country or the whole region. Paper seeks a deeper understanding of the planning capacity and argues that EUFOR Althea and EULEX Kosovo have achieved a somewhat satisfactory planning capacity level in the given circumstances in which the missions were planned and have been implemented, however a lot of room for improvement still remains.

The article contributes to the general literature on EU conflict prevention in the Western Balkans (and beyond). Its findings have implications for the theory and practice of operational conflict prevention in a way that it attempts to scrutinize the two CSDP engagements by merging top-down (EU staff and member states' representatives) with the bottom-up views (NGOs and local staff) related to the planning capacity of both missions.

\section{EU and the Western Balkans}

The two ongoing missions in the Western Balkans are certainly among the most ambitious CSDP endeavours concerning planning capabilities. They are both still operating under executive powers. The EU has been active in the Western Balkans to support countries which have undergone a period of violence in their recent history but also to directly influence stability of a region in EU's proximity with a perspective of EU membership. The EU's approach to the Western Balkans is based on strategic objectives aiming at an eventual membership of countries of the region in the $\mathrm{EU}^{3}$ and Kosovo is the biggest recipient per capita of EU assistance in the world. ${ }^{4}$

After Kosovo conflict ended in 1999, United Nations Security Council (UN SC) approved Resolution 1244, authorising military and civilian intervention and created UN Interim Administration Mission in Kosovo (UNMIK). Transfer of some of UNMIK's powers to the EU followed in 2008 and EULEX remains EU's biggest civilian mission in its history, created with a Joint Action Resolution in 2008. ${ }^{5}$ The EU aimed to establish and strengthen significant parts of the rule of law in Kosovo and create accountable and sustainable institutions in the area of justice, security and good governance, which are critical part of conflict prevention measures. In June 2016, the Council of the EU extended the mandate of the mission until June 2018 and provided over 60 million Euros for the mission's budget. ${ }^{6}$

The war in $\mathrm{BiH}$ ended in 1995 with the assistance of the international community under auspices of NATO after the official signing of the Dayton Accords 14 December 1995.

3 Council of the EU 2004a; European Commission 2018.

4 Cierco and Reis 2014.

5 Council of the EU 2008b.

6 Council of the EU 2015. 
NATO's first operation Implementation Force (IFOR) with over 60,000 troops became operational in December 1995 and NATO's presence in BiH in the following nine years ensured successful implementation of the Dayton Accords. ${ }^{7}$ On 9 July 2004 United Nations Security Council (UNSC) welcomed the intention of the EU to provide for the new operation in $\mathrm{BiH}$ and authorized the EU operation to proceed in November 2004 with the UNSC Resolution 1575. Althea is the longest-running military intervention launched in the framework of the CSDP. It was deployed under the Berlin Plus Agreement, ${ }^{8}$ the EU utilising NATO's assets and capabilities when planning the operation. ${ }^{9}$ The EU therefore entered the region after other organisations already established main conflict prevention or rule of law activities on the ground.

$\mathrm{BiH}$ is a potential EU candidate country, which negotiated and signed the stabilisation and association agreement (SAA) in 2008 and submitted its application for EU membership officially in February 2016. The EU also provides a single person for the post of the EU Special Representative in $\mathrm{BiH}$ and the Head of the EU Delegation. Similarly, Kosovo is a potential candidate for EU accession and its SAA entered into force in April 2016. After independence in 2008, the country stated that it has a 'clear European perspective.' The EU also appoints a Special Representative in Kosovo and a Head of the EU office. ${ }^{10}$

\section{Common Security and Defence Policy}

The Maastricht Treaty ${ }^{11}$ was the first to identify EU's objectives concerning external and foreign relations in 1992 since the EU realized it had no power over conflict in its immediate neighbourhood. EU member states began developing the two key levels of common crisis management capabilities: Common Foreign and Security Policy (CFSP), focusing on strategic foreign policy objectives and, a couple of years later, European Security and Defence Policy (ESDP), which aimed at operational execution of crisis management.

The St. Malo declaration ${ }^{12}$ and the Treaty of Amsterdam ${ }^{13}$ expressed the need for operational capabilities, the latter integrating crisis management into CFSP. In 1999, the European Council approved the Action Plan for Non-military Crisis Management and

\section{Knezović 2005.}

8 The Berlin Plus agreement is a comprehensive package of arrangements finalized in 2003 between the EU and NATO, which enables EU to make use of NATO assets and capabilities for EU-led crisis management operations.

European External Action Service 2016.

9 Council of European Union Secretariat 2015.

10 European Commission 2018, De Munter 2016.

11 European Union, Treaty on European Union, Treaty of Maastricht, signed 7 February 1992 in Maastricht, in force from 1 November 1993.

12 European Union 1998.

13 European Union 1997. 
development of institutional structures for its implementation. ${ }^{14}$ ESDP, established at the 1999 European Council meeting in Cologne and renamed CSDP after the Lisbon Treaty, ${ }^{15}$ became operational in 2003 with the launch of the first CSDP missions. Both missions analysed in this article were planned in this first wave of missions with a high level ambition for the EU to become a serious authority in terms of conflict prevention.

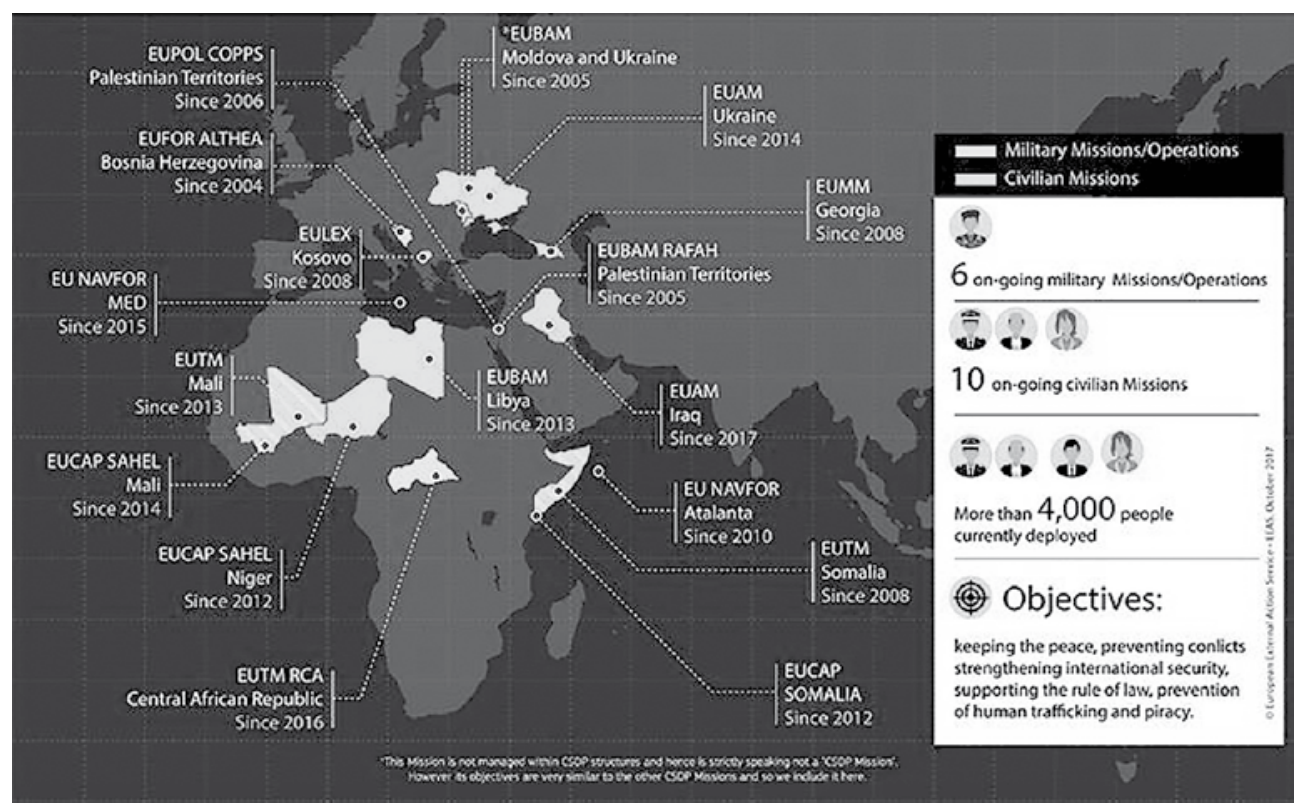

Figure 1: Military missions and operations ${ }^{16}$

There are currently ten civilian CSDP missions on three continents. Generally the planning process within the EU takes up to one year, in some cases, where a strong political will is exhibited even less. In the case of Kosovo, due to several reasons, the planning was stretched over a longer period. ${ }^{17}$ Planning process of EUFOR Althea lasted nine months nevertheless the planning processes of CSDP military operations can vary greatly.

14 Gourlay 2006.

15 European Union 2007.

16 European External Action Service 2018.

17 Grilj and Zupančič 2016. 


\section{Methodological Framework ${ }^{18}$}

There has been a large amount of academicresearch on CSDP missions in Kosovo and $\mathrm{BiH} .{ }^{19}$ Majority of work however has rather focused on the analysis of either specific peace mission and operation during a certain period of time through contributions of individual countries or contribution of a specific country to different missions and operations. ${ }^{20}$ This article is comparing two missions in order to analyse the lessons learnt in the civilian and military CSDP planning in a certain region, which is of significant importance to the EU. The article is drawing on 72 structured interviews conducted in Kosovo, $\mathrm{BiH}$, Brussels, Finland, Slovenia and elsewhere in 2015 and 2016. A set of indicators that allow differentiation between success and challenges of both missions in terms of planning has been developed. All preliminary research findings were afterwards 'tested' in two focus group discussions ${ }^{21}$ and several policy dialogues. The interviewees and the focus groups participants - EU personnel, governmental and non-governmental actors in Kosovo, $\mathrm{BiH}$ as well as other EU and member states' representatives - were asked to scrutinize the mission they have experience with according to the previously mentioned set of indicators. Due to the sensitivities of the issues discussed, the names of the interviewees are not disclosed.22 Analysis of primary and secondary sources served as a supportive research method. It was important that the topic was analysed from the inetervener's perspective, the EU as well as from the perspective ofthe local population, the non-EU perspective. This approachprovided a good overview of different opinions and viewpoints. ${ }^{23}$

18 This article is based on deliverable D2.3 of the IECEU Project (http://www.ieceu-project.com/). The responsibility for the content of the article lies solely with the authors and the opinions expressed therein do not reflect the official position of the European Union. Deliverable is based on data collection and interviews conducted by R. Zupančič, J. Suhonen, K. Sainio, E. Norvanto, J. Salonen, I. Boštjančič Pulko, M. Muherina and B. Udovič.

19 The literature on EUFOR Althea and EULEX Kosovo include the following publications: Bertin 2008; Keohane 2009; Juncos 2013; Boštjančič Pulko, Suhonen, and Sianio 2017; de Wet 2009; Mattelaer 2010; de Guttry 2007; Grilj and Zupančič 2016.

20 Jelušič 2016.

21 IECEU Roundtable of experts 2016 and 2017 in Slovenia. More than fifteen representatives of European External Action Service, NGOs, academia, ministries of foreign affairs, interior and defence, Armed Forces and former mission staff with proven CSDP experience took part in two discussions.Video from the round table with statements of the representatives taking part is available here: http://www.ieceu-project.com/?p=536.

22 The interview data and details are in the possession of the authors. Both missions provided researchers a list of interviewees, consisting of missions' top management, heads of departments as well as other national and local staff.

23 Mekri 2016. 


\section{CSDP Planning Capacity}

Planning process provides the conceptual bridge between the EU's political aims and objectives on one hand and the operational means and resources on the other. ${ }^{24}$ Planning capacity is one of the most important CSDP features, if coceptualised wrongly, the mission will consequently have limited possibilities of achieving success on the groud. Planning dynamic does not only govern decision-making process running up to the launch of the mission, but also the maintenance of political oversight by means of periodic mission reviews and adapting mission aims to the realities on the ground. Planning capacity is therefore key to understanding how an operation works.

Planning is a very multi-layered process. Political authorities on the political-strategic level of institutions in Brussels first define (in clearly defined consecutive steps) the broad outlook of the mission/operation. At various levels below - military-strategic (if applicable), operational and tactical - a process is started in which the guidance from the level above is analysed and translated into plans with increased levels of detail. ${ }^{25}$ When both Western Balkans missions were planned the EU crisis management concept and procedures only started to develop. Generally, the planning process should take up to a year or less. Between 2000 and 2003 the EU developed the crisis management procedures to facilitate the effective coordination in the following way: 1) Monitoring and exchange of information are carried out within the Political and Security Committee (PSC). If the PSC considers that EU action is appropriate, the planning process begins; 2) Elaboration of a Crisis Management Concept (CMC) follows when EU political interests, aims and objectives are designed; 3) Development of Strategic Options is the phase when the $\mathrm{CMC}$ is finally adopted by the Council and presents the basis for developing military or civilian strategic options. This is prepared either by the EU Military Committee or by the Committee for Civilian Aspects of Crisis Management (CivCom); 4) Formal Decision to take action and preparation of planning documents comes when the Council adopts the Joint Action drawn up by Working Group of Foreign Relations Counsellors (the Relex Group). Joint Action is a legal act establishing the mission and appointing the Operation Commander/Head of the Mission and determining financial issues. Concept of Operation (CONOPS) is a document defining how the operation will be implemented and Operational Plan (OPLAN) describes how the operation will be organized. The intervention is launched by the Council when OPLAN is approved; 5) Political control and strategic direction of interventions is implemented through the PSC; 6) The PSC also decides whether interventions should be refocused or terminated, which is based on the lessons learned process. ${ }^{26}$

By 2010 EU already had officials with field experience from previous CSDP interventions in $\mathrm{BiH}$, Macedonia and Indonesia and it was argued that strong individual leadership on

24 Mattelaer 2010.

25 Ibid.

26 Rehrl and Weisserth 2010. 
all levels, in Brussels and in the field, is one of the key factors for the missions to succeed. ${ }^{27}$ Council Conclusions on $\mathrm{CSDP}^{28}$ from 2011 reviewed and captured lessons learnt in crisis management processes over the first decade of ESDP/CSDP and CSDP structures. Existing Crisis Management Procedures (CMP) had to be reviewed in view of the implementation of the Lisbon Treaty and the establishment of the European External Action Service (EEAS), specifically Civilian Planning and Conduct Capability (CPCC) and the Crisis Management and Planning Directorate (CMPD). They also needed to take into account lessons learnt and consolidate the established practice in order to be more effective. CMP should help facilitate implementation of a comprehensive EU approach since the EU Crisis Response System, established as part of the implementation of the Lisbon Treaty, provides a framework for the EU's reaction to a crisis, which should allow faster decision making in response to a crisis if political consensus has been achieved. ${ }^{29}$

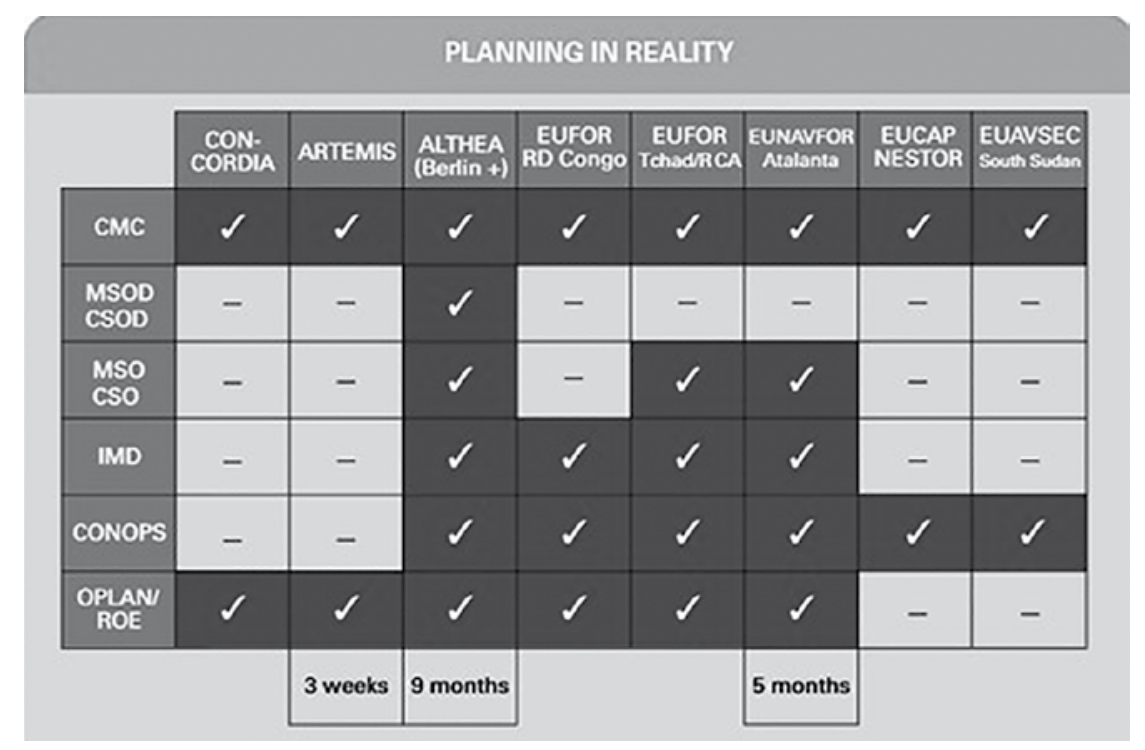

Figure 2: Planning of EU military operations in reality ${ }^{30}$

Crisis management procedures from 2013 remain the guidelines for planning the CSDP missions and operations at the political strategic level. PSC exercises, under the responsibility of the Council and of the High Representative, the political control and strategic direction of the crisis management operations in accordance with Article 38 of the Treaty

\footnotetext{
27 Penksa 2010.

28 Council Conclusions 2011.

29 Rehrl 2014.

30 de Kermabon 2014.
} 
on European Union (TEU). ${ }^{31}$ The EU has invested in reform of the CSDP planning structures in the last decade. Main findings of the Council's Concept Note from 2017 stress that CSDP should become more responsive and faster, as part of and in coherence with wider EU efforts. This will contribute to timely CSDP strategic planning as part of an integrated, comprehensive EU approach which seeks concrete civilian-military synergies, while recognising the importance of Member States involvement. ${ }^{32}$

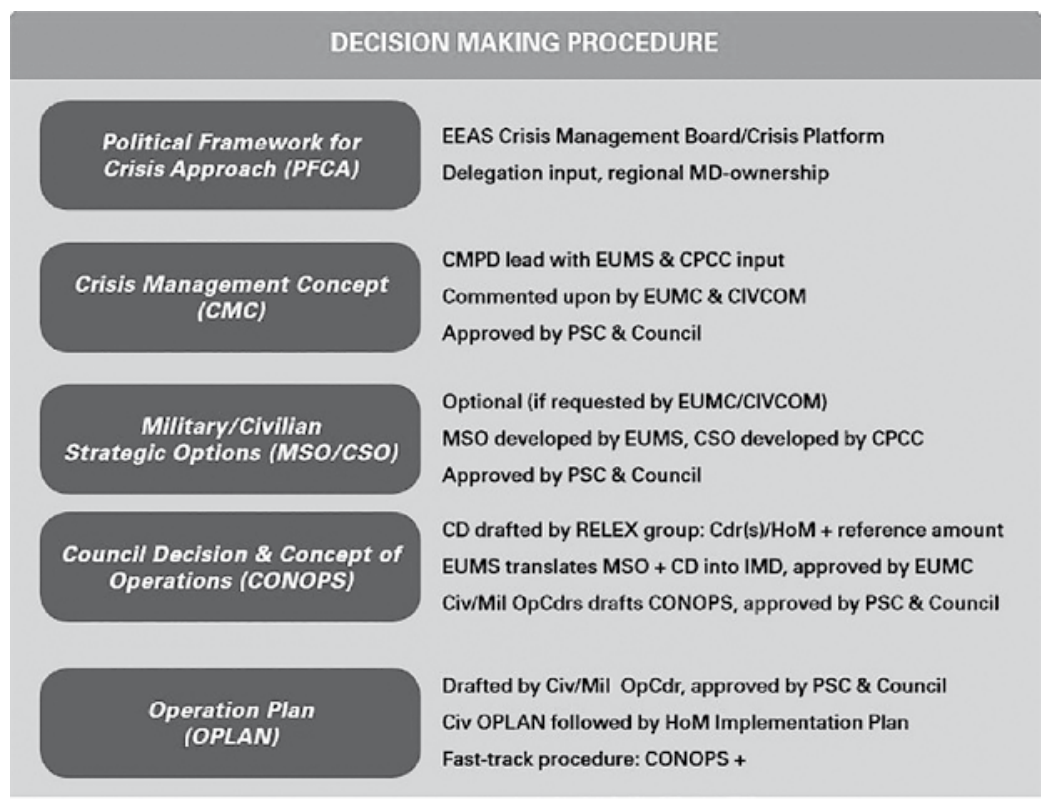

Figure 3: CSDP Decision Making Procedure ${ }^{33}$

During the political strategic CSDP planning process, a joined-up way of working should be implemented. Special attention should be given to opportunities for civ/mil synergies by associating under CMPD's direction all other relevant actors from the EEAS and Commission services. Such teamwork should be maintained in further phases with the lead responsibility shifting accordingly to the operational planning. The intended 'oversight' at the political strategic level should fully respect the need for clear civilian and military chains of command and control at the operational level: the commanders, both civilian and military, report directly to PSC on the operational planning and conduct of their missions and operations. Chairman of the Military Committee is the primary point of contact for military Operation and Missions Commanders. Mandate and progress of an operation

31 Council of the EU 2017.

32 Ibid.

33 Mattelaer 2017. 
or mission are periodically assessed through Strategic Reviews, which are submitted to the PSC for guidance. ${ }^{34}$

Certain innovations have been introduced in CSDP in the wake of the EU Global Strategy (EUGS) in 2016: an operational unit for the management of non-executive EU military operations, namely the new Military Planning and Conduct Capability (MPCC) unit headed by the Director General of the European Union Military Staff (EUMS). Some other units were also reorganized under the Deputy Secretary General for CSDP and Crisis Response. Since the EUGS, the topic of migration management is gaining in importance. The aim to reform EU crisis management structures is evident in particular with the establishment of PRISM $^{35}$ in the EEAS, which is perceived as a promoter for the EU's new Integrated Approach and is meant to bring about more coordination between all actors. There is still a considerable degree of uncertainty whether PRISM is meant to build up new expertise for the steering of stabilization actions and whether the stabilization actions under Article 27 of the Lisbon treaty would be predominantly small-scale, with limited scope, or can they potentially also be larger and long-term. ${ }^{36}$ Despite the functionality of the CSDP planning process, it seems the new structures have not brought the desired effectiveness.

\section{Planning Capacity of EULEX Kosovo}

EULEX is the largest CSDP mission so far and also the most complex, expensive and one of the longest lasting EU civilian CSDP missions, a flagship CSDP mission from the aspect of the dedicated financial and human resources. ${ }^{37}$ Objectives of EULEX go beyond common peace-keeping and engage in institution and state building. ${ }^{38}$

The UN Secretary General appointed Mr. Martti Ahtisaari as his special envoy tasked with preparing the proposal on the future status of Kosovo. In March 2007, he presented his proposal entitled "Report of the Special Envoy of the Secretary General on Kosovo future status" to the UN Security Council, which envisaged the deployment of an ESDP mission. The mission's purpose should be: 1) to assist in the development of the Rule of Law institutions; 2) to have authority to ensure the investigation and prosecution of specific crimes by independent international prosecutors and judges; 3 ) to have authority over limited executive functions to ensure the rule of law, public order and security. ${ }^{39}$

\footnotetext{
34. Council of the EU 2017.

35 PRISM stands for 'Prevention of Conflicts, Rule of Law/Security Sector Reform, Integrated Approach, Stabilisation and Mediation'.

36 Pietz 2017.

37 Keukeleire and Thiers 2010.

38 Papadimitriou and Petrov 2012.

39 Guttry 2007.
} 
To support the Kosovo's rule of law authorities to become independent, multi-ethnic, accountable, sustainable and free from political interference, EULEX was at the beginning divided into three main divisions covering Police, Customs and Justice. In 2012 downsizing of the mission by about 25 per cent occurred along with restructuring into two sections..$^{40}$ The Executive Division works on the mission's executive mandate, carrying out the rule of law services in accordance with the Kosovo law, instead of local authorities, until they become sufficiently qualified to take over. The Strengthening Division supports Kosovo judicial authorities and law enforcement institutions in establishing higher levels of accountability and sustainability. It seems that the new, reconfigured mission structure is better at addressing the needs, division of responsibilities and tasks more comprehensively. ${ }^{41}$

Several analysts concluded that the mission made only limited progress in the field of judiciary, especially in relation to the organized crime and corruption, while modest contributions to other aspects of the rule of law are noted (e.g. police and customs). ${ }^{42}$ The organizational allocation of the judges and prosecutors in EULEX is problematic since the norm of judiciary independence is not guaranteed and respected in its constitutional meaning of separation of powers - the police, prosecutors and judges are all part of the same organisational division and true separation of powers and judiciary independence is not really possible. ${ }^{43}$ The whole decision making process of CSDP is criticized as too complex and lengthy, which leads to addressing the concerns of managing the mission itself, rather than attending to the continuously new challenges arising from its mandate. ${ }^{44}$ The political significance of deployment of the mission and the statement EU is making with it can overtake the importance of its efficiency. ${ }^{45}$

\section{Strategic Level Planning}

EU civilian crisis management procedures were in their development phase at the time of EULEX Kosovo planning. The CPCC was only established in 2007 under the General Secretariat of the Council with about 60 staff. ${ }^{46}$ The CPCC Director is the EU Civilian operations Commander, exercising control and command at the strategic level for the planning and conduct. EULEX was preceded by the formation of the EU Planning Team

\footnotetext{
$40 \quad$ Interview nr. 9.

41 Interview nr. 9, 10 and 11.

42 Zupančič 2015. Interview nr. 9, Interview nr. 10, Interview nr. 11.

43 Interview no. 3, 16.

44 Interview no. $5,7$.

45 Interview no. 4.

46 It has a mandate to: 1) plan and conduct civilian missions under the political control and strategic direction of the PSC; 2 ) provide assistance and advice to the High representative of the Union for Foreign Affairs and Security Policy; 3) direct, coordinate, advise, support, supervise and review the civilian mission in the areas of the police, border assistance management, rule of law and the security sector.
} 
(EUPT), tasked to conduct advance contingency planning for the possible deployment of the EU mission on the territory of Kosovo. ${ }^{47}$ EUPT was deployed to Kosovo with the Joint Action 2006/304/CFSP ${ }^{48}$ in April 2006 to prepare the ground for a possible EU crisis management mission in the field of rule of law and possible other areas ${ }^{49}$ Deployment of EUPT prior to the mission was mostly assessed as a positive practice that should be replicated in future CSDP missions.$^{50}$ EUPT benefited from its local presence in Pristina, its full support of the Council Joint Action, the budget, as well as the comparatively lengthy time it was given to work..$^{51}$ EUPT had a role in the initial deployment phase of EULEX as defined in Article 4 of the Joint Action 2008/124/CFSP on the European Union Rule of Law Mission in Kosovo. EUPT Kosovo was appointed to lead the planning and preparation phase, it was responsible for the transfer of responsibilities from UNMIK to the EU, to prepare all the necessary legal acts, to work in the field, to learn about the local needs and expectations, for the recruitment and deployment of staff, equipment and services for EULEX in the initial phase when the mission had not yet reached its full operational capacity. It worked in the field to identify the local needs and discuss the forms of cooperation with local authorities. EUPT also contributed to the planning of the CONOPS and OPLAN and for developing the technical instruments necessary to execute the mandate of EULEX. ${ }^{52}$ A challenge present in the planning and still evident is the understaffed CPCC dealing with EULEX, as only two officers are assigned specifically for EULEX. This is unsatisfying for the mission staff in the field as the communication is occasionally delayed and the procedures take too long. ${ }^{53}$

EUPT began its planning without clarity regarding the future political status of Kosovo, with the risk of failure in implementing the Ahtisaari Plan, and no clear timeline regarding the UN transfer of authority. ${ }^{54}$ Directorate-General for External Policies of the Union's analysis exposed EU's (over)confident trust in the success of the Ahtisaari plan, which was not approved by the UNSC. ${ }^{55}$ Mission was initially envisioned as an integral part of the Ahtisaari plan and the framework of the mission had to be re-structured. ${ }^{56}$ The mission mandate from February 2008 tasked EULEX with supporting Kosovo authorities by monitoring, mentoring, and advising (MMA) on each of the rule-of-law components (Judiciary, Police, Customs), while also retaining certain executive powers, in particu-

47 Douglas 2016.

48 Council of the EU 2006.

49 Ibid.

50 Interview no. 20.

51 Directorate-General For External Policies of the Union 2012.

52 Council of the EU 2008a.

53 Interview no. 5.

54 Penksa 2010.

55 Directorate-General For External Policies of the Union 2012.

56 Douglas 2016. 
lar with respect to investigating and prosecuting serious and sensitive crimes.$^{57}$ EULEX raised high expectations in Kosovo among the local population, giving big promises of reforming the rule of law, the implementation of the European legal norms, elimination of political interference, and going after "big fish" ${ }^{58}$ It was however quickly subject of severe public criticism due to its failure to deliver on its promises and even allegations of possible corruption among EULEX officials. ${ }^{59}$

There was a difference between the last document of the EUPT, when its representatives were planning the mission, and the first EULEX OPLAN. ${ }^{60}$ The mandate always derives from the political will of the member states and may not completely reflect the needs on the ground. It is still questionable whether the mandate of EULEX was reconcilable with the Security Council Resolution 1244 and if the resolution gave the necessary legal basis for the introduction of EULEX. The mission was intended to operate alongside UNMIK and how were these two missions supposed to operate side by side given the potential overlaps in their mandates was not clear. ${ }^{61}$ EULEX was limited in its deployment phase which led to delays beyond the initial EU forecasts. ${ }^{62}$ It actually took around two years for deployment of the mission to Kosovo. The EU was therefore able to agree on deploying the mission but did not manage to form a unified position regarding the announced Kosovo independence since five member states did not recognize it. The EULEX status neutral position had far-reaching effects. ${ }^{63}$

Kosovo status issue deliberations confirm that the EU is capable of acting as a foreign policy actor when contributing to the peace-building efforts by other actors (e.g. UN), but having trouble finding a consensus on politically sensitive matters when acting on its own. ${ }^{64}$ EULEX mandate declared the mission to be status neutral and at the same time tasked it with strengthening the rule of law institutions of the independent Kosovo, which is at least partially self-contradictory. ${ }^{65}$ Many the interlocutors agreed that it is actually quite impressive what EULEX managed to achieve in the given circumstances since it had to address the considerations from both Kosovars and Serbs. The neutral approach tries to "please" both sides and it was also stressed that the needs of Kosovo were conceptualized wrongly, that for example there is too much emphasis on the war crimes, whereas the local population would rather see more focus on dealing with corruption cases. ${ }^{66}$ There is

57 Grilj and Zupančič 2016.

58 Interviews no. 9, 10, 18, 19, 20.

59 Interviews no. 5, 9, 10, 17, 18, 19.

60 Interview no. 9.

61 de Guttry 2007.

62 Keukeleire and Thiers 2010.

63 Derks and Price 2010.

64 Keukeleire and Thiers 2010.

65 Interview no. 19.

66 Interviews no. 1, 9, 10, 15, 18, 19. 
also a well elaborated analysis and lessons learned process, only the implementation of the findings on the operational level is rather weak. ${ }^{67}$

\section{Operational Planning Capacity}

A compromise solution was needed for the EU, the USA, the Kosovo government, the Russian Federation, Serbia and the Kosovo Serbian minority before EULEX could become operational. ${ }^{68}$ In June 2008 the UN Secretary General proposed the operational role of EULEX, under the overall authority of the UN Special Representative (conforming to the framework provided in the UN Security Council Resolution 1244). ${ }^{69}$ Due to differences in the interpretation of what this proposal would imply in practice, deployment of EULEX was delayed for several months. In November 2008 the UN Security Council adopted Secretary General's report in which all the aforementioned actors, except for the Kosovo government, reached a concrete agreement regarding the functionality of six areas: police, justice, customs, transportation and infrastructure, boundaries and Serbian patrimony. ${ }^{70}$ EULEX could deploy its first units, which by that time amounted to less than 500 personnel, or one quarter of the planned 2000 personnel. ${ }^{71}$ In the transition period EULEX had to accept coexistence with UNMIK and execute its mandate without a conflict with the UN. The operational phase of EULEX started upon the transfer of authority from UNMIK (120 days period). During that transition period the Head of EULEX delegated the responsibility to undertake the necessary activities for EULEX to be fully operational to EUPT. $^{72}$

EULEX was deployed to Kosovo in 2008 at a politically very sensitive time. Kosovo declared independence and several EU member states and non-EU states have not recognised it up to this day. This fact led to several political compromises that impacted operational capabilities of the mission. The question of which law to apply in the functioning of the rule-of-law mission was raised by EULEX prosecutors and judges at the very beginning. Furthermore, due to political uncertainties, the mission faced challenges related to the available qualified staff that the participating states were willing to second. The limitations were reflected also in the OPLAN and concrete operational limitations, such as the access of EULEX personnel to the North of Kosovo. ${ }^{73}$ Locals stressed that the most pressing needs by the Kosovars are not taken into account by the mission since the 'stability mantra' seems to be the matter of vital importance, even when compromises in the rule of law are made. EULEX is most often criticized by locals for its inability to successfully

67 Interview nr. 9.

68 de Wet 2009.

69 Ibid.

70 Ibid.

71 Ibid.

72 Council of the EU 2008a.

73 Interview no. 19. 
transform the Kosovo rule of law system and complete its lengthy legal procedures, which could potentially lead to convictions in high level cases. ${ }^{74}$

The CPCC administrative procedures are assessed as burdensome, there is a lack of a clear "Brussels" leadership, home countries of seconding staff are often not interested in the information they provide to their respective ministries, which leaves the staff unmotivated. ${ }^{75}$ Despite the challenge of the EEAS structure, member states seem to be reluctant when it comes to the possibility of increasing the funds and carrying additional financial burdens. Mission staff requests to 'Brussels' are occasionally delayed and procedures take too much time. Reporting is occasionally mismatched with the discussions in Brussels and reports often do not have the desired impact. Challenges related to international mission staff have been evident early on from the formation of the mission and can be attributed both to the (un)availability of the staff, their (lack of) competences and the (short) durations of the deployments of international seconded staff. Both international and local staff interviewed for this research noted the negative implications of relatively short term deployments and exposed certain limitations in staff pre-deployment training. ${ }^{76}$

Especially concerning is the situation present in judiciary branch, as majority of member states do not second their best judges and prosecutors, or are not seconding a sufficient number of judicial staff at all. Duration of deployments can be problematic in relation to the relatively lengthy judicial proceedings since the same judge or a prosecutor often cannot conclude some of the lengthier and more complex cases, as his or her mandate expired within the course of the proceedings. Those are consequently passed to his or her successor which inevitably delayed the process. ${ }^{77}$ Better planning of human resources and training of the deployed staff seems crucial. Perhaps even more fundamental than the above-mentioned challenges is the mission's lack of clearly set benchmarks and end state. The mission statement perceives a desired end state through sustainable and accountable Kosovo institutions, judicial authorities and law enforcement agencies, an independent multi-ethnic justice system and a multi-ethnic police and customs service, free from political interference and adhering to internationally recognized standards and European best practices. ${ }^{78}$ The lack of a clear end-state does not help in preventing the CSDP engagements from being seen as 'eternal' and without 'feasible goals' by the local communities since it is hardly imaginable that the mission could achieve the overall goals of the mandate in the foreseeable future. ${ }^{79}$ On the other hand, CSDP missions in general are

74 Grilj and Zupančič 2016.

75 Interviews no. 16, 19.

76 Interviews no. 1, 3, 4, 7, 8, 10, 11, 13, 15, 16, 20.

77 Jacque 2015.

78 Council of the European Union 2008a.

79 Interviews no. 4, 16, 18. 
political tools, and as such their deployment and potential closure is essentially a political rather than a technical decision. ${ }^{80}$

Aside from its office in Belgrade, EULEX no longer has field-regional offices, although it maintains a larger presence in the North of Kosovo. Situational information is shared with the mission through the internal hub, coordinated by the Office of the Chief of Staff. Additionally, other EU intelligence resources are used for operational purposes, including threat assessment, which helps drawing a clearer situational picture. ${ }^{81}$ The need to improve situational awareness on strategic levels for the purpose of informed political decisions has been identified. Various important issues that should have been raised on a political or diplomatic level have not been discussed also due to the lack of timely and accurate situational awareness information. ${ }^{82}$ Improved overall situational awareness could improve comprehensiveness and coordination between EU actors in Kosovo and enhance the responsiveness of the EU to a changing environment in Kosovo. 'Brussels' tends to get in too many details (some sort of "micro-management") with the lack of accurate information from the field and fails to establish a clear strategic framework, which would allow the field staff to develop effective Mission Implementation Plans (MIPs) on operational level. The lack of a strong strategic leadership, a practically non-existent effective operational level, and great pressure on the tactical leadership, have been pointed out as the indicators of a poorly balanced mission management. ${ }^{83}$

The EU has been recently investing more efforts into identification, analysis and implementation of the lessons learned in its planning process. For example, EULEX leaders responsible for individual MIPs have been brought to Brussels to share their experience, lessons learned and opinions to foster the future planning process. ${ }^{84}$

\section{Planning Capacity of EUFOR Althea}

EUFOR Althea is often referred to as the first major military operation of the EU and after thirteen years of functioning, it is also known as the longest EU operation in its history. ${ }^{85}$ The goal of the EUFOR Althea mission was at the time of its inception to ensure continued compliance with the Dayton Accords, to contribute to safe and secure environment (SASE) in $\mathrm{BiH}$ and to support the Euro-Atlantic integration of the country. ${ }^{86}$

80 Interviews no. 4, 18.

81 Interview no. 20.

82 Interview no. 17.

83 Interview no. 16.

84 Interview no. 4.

85 Knauer 2011.

86 Kim 2006. 
EUFOR Althea's mandate has been reconfigured four times, most recently in 2012. Objectives of the operation changed and now encompass provision of capacity-building and training (CBT) to the Armed Forces of $\mathrm{BiH}$, support to the country's efforts of maintaining SASE and support to overall EU comprehensive strategy for $\mathrm{BiH} .{ }^{87}$ Additionally, EUFOR Althea's engagement in Security Sector Reform (SSR) and defence reform is covered due to its linkage with CBT. ${ }^{88}$

The planning capacity of EUFOR Althea profited greatly from the access to NATO planning assets, structures, and capabilities under Berlin Plus, along with infrastructure on the ground, provided by NATO's SFOR mission. In principle, a clear military command structure, a solid reporting system, and the availability of NATO assets provide a very good basis for real-time situational awareness. ${ }^{89}$

EUFOR Althea was launched when the future of $\mathrm{BiH}$ mattered not only for maintaining peace and security in the EU's neighbourhood but also for the EU's self-perception as a foreign policy and security actor. ${ }^{90}$ It contributed to the EU's development from a civilian power to a more multifaceted one, resorting to military instruments with an aim of promoting its own values and goals. EUFOR Althea enabled the EU to experiment with its military capabilities in a relatively safe multi-actor environment. ${ }^{91}$ France, together with Britain and Germany, started to push for deployment of a CSDP successor operation to SFOR in early 2004. France namely wished to reduce its military presence in $\mathrm{BiH}$ as part of SFOR and add credibility to CSDP. Franco-German Defence and Security Council (FGDSC) declared both countries' full support for EU's takeover of SFOR in early $2004 .{ }^{92}$ Key issue throughout the CSDP's history was the relationship of EU military engagement with NATO. In the context of EUFOR Althea, this particular issue involved the question of whether or not to include the fight against organized crime in EUFOR's mandate since NATO wanted to retain this aspect. ${ }^{93}$

Negotiations with NATO over terms of SFOR's handover and the EU's own planning process for the operation took two full years due to complicating negotiations with the United States and NATO. EU Member States specifically wanted a clear division of labour between the EU force and the remaining NATO elements in $\mathrm{BiH}$ once the EU would take over SFOR. The heads of state and government of NATO Member States decided in their June summit in 2004 that certain operational supporting tasks in Bosnia would remain

87 Council of European Union Secretariat 2015.

88 Interview no. 21.

89 Ibid.

$90 \mathrm{BiH}$ has many times been referred to as a 'testing ground' for CSDP. Council of the European Union, 2004b.

91 Juncos 2015.

92 Ministère des Affaires étrangères et européennes. 'Declaration du Conseilfranco-allemand de défense et de sécurité. Paris, France; 22 January 2003.

93 Palm 2017. 
under NATO's powers after the termination of SFOR in December, such as counter-terrorism and tracking war criminals. ${ }^{94}$ The EU initially deployed 7,000 troops from $22 \mathrm{EU}$ member states and 11 other countries deployed under Chapter VII of the UN Charter to ensure continued implementation of and compliance with Annex 1-A and Annex 2 of the Dayton Agreement and to contribute to SASE. ${ }^{95}$ Large number of SFOR troops remained in $\mathrm{BiH}$ and were only transferred under the command of EUFOR Althea, which was assessed as operationally smooth due to the use of 'Berlin Plus' arrangements and the existing SFOR operation plans which formed the basis for EUFOR Althea's strategic and operational planning. ${ }^{96}$ Most troops were provided by Germany, the UK and Italy, followed by the Netherlands, Spain and France. Cyprus, Malta and Denmark were the only member states not contributing any troops. Transition from SFOR involved the withdrawal of the US but most EU troops remained and the US presence was primarily taken over by Finland, succeeded by the end of 2005 by Austria. ${ }^{97}$

The 2004 Council Joint Action has not been officially amended but character of the mission was significantly revised in 2007 when the number of troops was decreased to 2,500 and the position of the EU Special Representative was strengthened. In 2010-2012, nonexecutive tasks were included in the operation and the number of troops was further decreased..$^{98}$ With the reconfiguration in 2012, EUFOR Althea's troop level dropped to approximately 600 , which is also its current strength. The reconstruction of the operation was driven primarily by the lack of political will and by withdrawals of participating nations. In 2007 the UK and the Netherlands withdrew their troops but the operation largely retained its main characteristics and the mandate of the operation was left unchanged, the executive mandate was neither removed nor expanded..$^{99}$ Troop reductions were primarily motivated by instrumental reasons, UK namely referred to its 'overstretch' in Iraq and Afghanistan ${ }^{100}$ but also because member states claimed the security situation in $\mathrm{BiH}$ had considerably improved.

EUFOR Althea is conducted under the authority of the European Council, political control and strategic direction is exercised by the PSC. The EU Military Committee (EUMC) monitors the appropriateness of its execution and the Chairman of EUMC acts as the primary point of contact for the operation commander (OpCdr), who is also a Deputy Supreme Allied Commander Europe (DSACEUR) in the NATO structure. DSACEUR is supported by the EU OHQ, which consists of Supreme Headquarters Allied Powers Europe (SHAPE)and the European Union Staff Group (EUSG). To ensure synergy and

94 NATO. 'Istanbul Summit Communiqué,' Istanbul, Turkey; 28 June 2004.

95 Kim 2006.

96 EEAS 2016. Interviews no. 21, no. 23, no. 32, no. 33 and no. 44.

97 Recchia 2007.

98 Palm 2017.

99 Ibid.

100 Oliver 2007:British troops to leave Bosnia', Guardian, 1 March 2007. 
prevent unnecessary duplication, the EUSG is closely interconnected with the SHAPE Comprehensive Crisis and Operation Management Centre (CCOMC). The OpCdr reports to the PSC through the chairman of the EUMC on all issues of strategic value for the operation and attends EUMC and PSC meetings. ${ }^{101}$

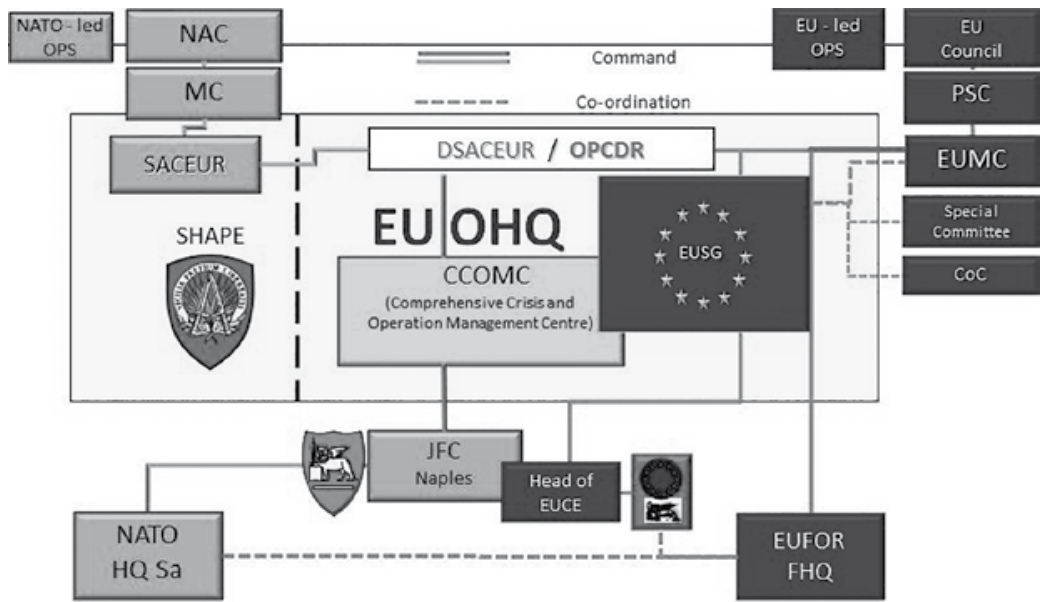

Figure 4: Command and control structure and responsibilities of EUFOR Althea 102

\section{Strategic Level Planning}

NATO common assets and capabilities are defined in the Specific Agreement for EUFOR Althea and comprise mainly Command and Control (C2) items such as Operation Headquarters (OHQ) at Supreme Headquarters Allied Powers Europe (SHAPE) and the EU Command Element (EUCE) at Joint Forces Command (JFC) Naples, Communication and Information Systems (CIS) and access to NATO's classified networks, namely intelligence systems and intelligence database as well as the infrastructure. ${ }^{103}$ NATO is considered to be much better at planning and resource allocation and some argue the operation is much more NATO-conducted than EU-conducted with a mandate being framed in member states' discussions, but the reality is given by DSACEUR, and sometimes NATO's input is significantly greater. ${ }^{104}$

Strategic-level planning by EUSG at $\mathrm{OHQ}^{105}$ also deals with force generation, manpower and organisation review, reporting system and financial issues. It provides updated in-

101 Interviews no. 21, Interview no. 65. EUSG 2016.

102 Interview no. 47; EUSG 2016; Boštjančič Pulko, Suhonen, Sainio 2017.

103 Interviews no. 21, no. 23, no. 32, no. 33 and no. 44.

104 Interviews no. 21 and no. 24.

105 European Union Staff Group 2016. 
formation and maintains situational awareness within $\mathrm{BiH}$. Theoretically, a clear military command structure, a solid reporting system, and the availability of NATO assets provide a very good basis for real-time situational awareness. However, the reduced number of troops and, especially, the current low number of liaison and observation teams (LOTs) ${ }^{106}$ in the field compromise ability to react and respond in a timely manner to a potential deterioration of the SASE. ${ }^{107}$

OHQ updates the operational plans as required in coordination with the NATO Strategic Operational Planning Group, it co-ordinates all operational matters, monitors current operations, and advises on all operational issues. OHQ also participates in operational planning and is responsible for the reserves concept, co-operating with troop-contributing nations (TCNs) and the EUCE with respect to intelligence and reconnaissance assets. In addition, it liaises with NATO on the Balkans Operational Reserve Forces and Strategic Reserve Forces. The role of the OpCdr as NATO-EU strategic coordinator and his wellfunctioning interaction with the EUFOR commander (COM EUFOR) was seen as a critical factor for operational success, as it was expressed by many interviewees. ${ }^{108}$

The command and control (C2) structure of EUFOR Althea is quite complicated on account of several 'layers' of political and military actors. The political-strategic level sometimes provides no coordination or planning guidance directed to the operational level, where it is also problematic that the EU as a whole does not have a common understanding on the preferred strategic development of the country and political realities limit the strategic/operational planning. ${ }^{109}$ The operation clearly lacks a clear end state. ${ }^{110}$ The mission staff often lack understanding of what is going on at the HQ level in Brussels but the same is also true vice versa. ${ }^{111}$

Member states' approvals of the mission's extension or its adjustment are crucial and sometimes a show-stopper to the planning process and execution. In 2010 the executive mandate was extended with inclusion of 'non-executive capacity-building and training support' for the $\mathrm{BiH}$ authorities. ${ }^{112}$ In 2012, another troop reconfiguration put even more emphasis on capacity building and training. ${ }^{113}$ Changes or adjustments of the OPLAN have to be approved by the member nation $\mathbf{s}^{114}$ and the mission seems to be quite low on the agenda of some member states. Nations consequently do not second their best staff

106 'Liaison and observation teams in EUFOR 2016.

107 Interviews no. 34, no. 24 and no. 40.

108 Ibid.

109 Interviews no. 25 and no. 34. Boštjančič Pulko, Suhonen, Sainio 2017.

110 Interviews no. 21 , no. 28 , no. 40 , no. 39 and no. 36.

111 Interview no. 21.

112 Council of the European Union 2010.

113 Interviews no. 21, no. 28.

114 Interviews no. 29 and no. 47. 
since they perceive it as a training opportunity for individuals not so much as a contribution to the EU success on the ground. ${ }^{115}$

Notwithstanding lack of coordination between political-strategic level and operationaltactical level, the interviewees perceived the current planning system based on NATO assets as functional and it is considered that the planning process takes all the necessary factors into account. The EUSG at OHQ is seen as 'the core', liaising with all the SHAPE Directorate's branches. ${ }^{116}$ The so called end state is listed very vaguely as "(...) to be based on progress in building efficient state level structures, in particular in the area of security and defence. This objective is primarily the responsibility of the $\mathrm{BiH}$ government assisted by EU civilian actors. Moreover, it will be important to avoid the creation of a culture of dependence upon EUFOR". ${ }^{117}$ Some of the interlocutors perceive that the continuation of the operation serves mainly the EU's political purposes. ${ }^{118}$

As stressed in the European Council recommendations from 2013 to increase the civilmilitary component in CSDP, civil-military synergies in $\mathrm{BiH}$ were unfortunately destined to be lost from the beginning since the two CSDP interventions, The European Union Police Mission in Bosnia and Herzegovina (EUPM) and EUFOR Althea were planned separately and there was no joint strategic planning or set of connecting structures. ${ }^{119}$

\section{Operational Planning and Execution}

When EUFOR Althea was deployed there were already OPLANs in place, prepared by SFOR and work continued largely in line with the existing plans. SFOR OPLANs formed the basis for EUFOR Althea's strategic/operational planning, which was a very practical contribution to EU's planning from the starting point. ${ }^{120}$ EUFOR Althea uses a 'standard military' operations planning process (OPP) and follows NATO's Comprehensive Operations Planning Directive (COPD). OHQ at SHAPE will update or develop the operational plans as required in coordination with the NATO Strategic Operational Planning Group. The key element at OHQ is the EUSG, which supports DSACEUR in his role as $\mathrm{OpCdr}$ and is responsible to him for the day-to-day running of the operation and operational planning. OHQ co-ordinates all operational matters and advises on operational issues, participates in operational planning and the development process for current operations. ${ }^{121}$ Subordinate units keep the higher levels informed of their planning through back-briefing, which enables dialogue between the various levels and COM EUFOR is

115 Interviews no. 28.

116 Interviews no. 24 and no. 47.

117 Council of the EU 2004a.

118 IECEU Roundtable of experts 2016. Boštjančič Pulko, Suhonen, Sainio 2017.

119 Interviews no. 22, no. 23, no. 31.

120 Interviews no. 21 , no. 23 , no, 32 , no. 33 and no. 44.

121 Interviews no. 21, no. 23, no, 32, no. 33. 
able to act, put the plan into action, and distribute the necessary orders/directives/guidance within the OPLAN framework. ${ }^{122}$

The OpCdr pays regular visits to EUFOR Althea, enabling face-to-face contact among the commanders, supporting COM EUFOR Althea's leadership, and giving direct strategic/ operational level guidance. ${ }^{123}$ The OPLANs at both the strategic-operational level (OHQ) and operation level (Area of Operation in $\mathrm{BiH}$ ) are reviewed in light of the security situation and the development of the operational environment in $\mathrm{BiH}$. OHQ OPLAN has been revised four times and COM EUFOR's OPLAN five times. ${ }^{124}$ The current planning process produces detailed co-ordinated plans is perceived as functional. However, the political guidance or member states' 'approval' linked to national interests/agendas related to extending or adjusting the mission, nominating reserves, or amending the operational plan slow down the planning process and execution. ${ }^{125}$

NATO still owns the very important strategic dimension of the reform process in $\mathrm{BiH}$ and is working closely with BiH Ministry of Defence. EUFOR, on the other hand, has an important role in the implementation of the technical and tactical aspects of the reform. Currently, NATO and EUFOR seek to co-ordinate their efforts to foster defence reform, with NATO's objective being to support developing the capacity of the defence sector in pursuit of NATO standards, thereby preparing BiH for possible future NATO membership. The EU aims to strengthen the country's security sector in order to ensure its consistent stability in connection with the EU integration process. ${ }^{126}$

Developing the CBT of the Armed Forces of Bosnia and Herzegovina (AFBiH) in close coordination with NATO is currently one of the key tasks of EUFOR but the comprehensive nature of BiH's defence reform unfortunately allows EUFOR's role to be minor when compared to other actors. ${ }^{\prime 27}$ The current stage of the operation may lead to a major

122 Bostjancic Pulko, Suhonen, Sainio 2017.

123 Interview no. 34.

124 Interviews no. 40, no. 41, no. 46 and no. 47.

125 Any major changes or adjustments to the OHQ level OPLAN have to be approved by the member nations. National caveats and national agendas were not seen as obstructing interoperability per se but were considered to be a phenomenon that presents challenges to operational planning. The issue of strong national agendas of certain individual nations (e.g. Turkey and Austria) is not seen as significantly hampering interoperability in practice.

Interviews no. 29, no. 34, no. 35 and no. 47.

126 As the EU and NATO requirements are in line with one another, the joint reform efforts can help both organisations reach their long-term goals for the country. One interviewee described the cooperation between the two organisations stating that no decision is taken on any aspect of SSR without the EUFOR and the NATO commander first discussing it, before approaching any local authorities. Interview no. 39.

127 EUFOR 2016. In 2012, the operation reconfigured and moved its focus to CBT for the AFBiH. It nevertheless retained its obligations to support the $\mathrm{BiH}$ authorities in maintaining a SASE; Council of the European Union 2010. Interviews no. 28 and no. 34. 
restructuring or might even be the first step towards the conclusion of the operation. Since 2012 Austria and Hungary are the main contributors. Broader debate over whether or not to terminate EUFOR Althea started already in 2008. The situation has stalled due to the political circumstances in $\mathrm{BiH}$, which are currently not favourable. In general, the political design of $\mathrm{BiH}$ is not conducive to completing all tasks. ${ }^{128}$ Interviewees stressed that the shift from initial implementation of compliance with the Dayton Agreement and from contributing to a SASE to providing CBT stems from the fact that the original mandate did not match the needs on the ground anymore. EUFOR Althea's current focus with CBT actually derives from the member states' inability to decide 'where to go' and their unwillingness to contribute troops and resources to the operation.

EUFOR Althea is currently implementing a highly integrated and jointly co-ordinated training plan with the AFBiH, together with NATO and several bilateral partners. Within this joint framework, delivering effective CBT requires careful coordination of all the efforts by international actors. This is critical as sometimes nations have been willing to provide training or donate equipment outside of the agreed training plan. In consequence, capacity and resources of EUFOR Althea and NATO HQ Sarajevo have become tied up for a long time in training the $\mathrm{AFBiH}$ in the use of particular equipment. Donations are sometimes politically linked to national interests. All this is reflected as a lack of sustainability of the capacity building efforts. ${ }^{129}$ Although the training is organised and planned very well, financial support is a considerable challenge. EUFOR Althea conducts training mainly with its own equipment. When training is completed, the trained $\mathrm{AFBiH}$ units should possess skills and knowledge needed but no equipment and assets to execute what they are trained for. Certain budget allocation should therefore be made for purchasing equipment and basic assets for the $\mathrm{AFBiH}$, since they have very limited resources to invest or procure practically any equipment. ${ }^{130}$

\section{Conclusion}

EUFOR Althea and EULEX Kosovo were created because the EU had been perceived as a legitimate actor to support development, reform and democratisation of countries in its immediate neighbourhood. ${ }^{131}$ By scrutinizing both missions, parallels can be drawn on lessons learnt regarding the set of planning capacity indicators, divided under success or challenges:

\footnotetext{
128 Interviews no. 28 and no. 52.

129 Interviews no. 36, no. 34, no. 39, and no. 24.

130 Interviews no. 36 , no. 34.

131 Hazelzet 2013. 


\begin{tabular}{|c|c|}
\hline EULEX & EUFOR Althea \\
\hline $\begin{array}{l}\text { Success indicators: } \\
\text { Deployment phase: EUPT's placement in } \\
\text { Kosovo in advance of EULEX with the task } \\
\text { of preparing the ground and proceed with the } \\
\text { planning process of the most extensive CSDP } \\
\text { mission to date; } \\
\text { The EU was able to find political compromise } \\
\text { and deploy the mission despite the challenges } \\
\text { arising from the question of Kosovo mandate } \\
\text { among EU members and in international com- } \\
\text { munity; } \\
\text { There is a well-elaborated mission analysis of } \\
\text { lessons learned; however, the implementation } \\
\text { of the findings on the operational level is weak; } \\
\text { Positive contributions in the field of police and } \\
\text { customs. }\end{array}$ & $\begin{array}{l}\text { Success indicators: } \\
\text { Deployment phase: Access to NATO planning } \\
\text { assets, structures and capabilities under the } \\
\text { "Berlin Plus" arrangements, which contributed } \\
\text { to a smooth and relatively simple transition } \\
\text { from SFOR to EUFOR Althea; } \\
\text { EU was able to find political compromise and } \\
\text { deploy the mission despite difficult negotia- } \\
\text { tions with NATO and little previous CSDP } \\
\text { military experience; } \\
\text { Current planning system based on NATO } \\
\text { assets is functional and the planning process } \\
\text { takes all the necessary factors into account; } \\
\text { Clear military command structure, reporting } \\
\text { system and the availability of NATO assets } \\
\text { provide a very good basis for real-time situ- } \\
\text { ational awareness; } \\
\text { Well integrated and jointly coordinated train- } \\
\text { ing plan with AFBiH together with NATO and } \\
\text { several bilateral partners. }\end{array}$ \\
\hline $\begin{array}{l}\text { Challenges: } \\
\text { - } \quad \text { Deployment phase: Quite lengthy; } \\
\text { The mission suffers from a lack of clear end- } \\
\text { state or exit/transition strategy; } \\
\text { Lack of official and clear time-limited bench- } \\
\text { marks; } \\
\text { The "political realities" and the member states' } \\
\text { role are crucial and a showstopper for planning } \\
\text { process and execution; } \\
\text { Short deployments of international staff not } \\
\text { contributing well to the efficiency of the work- } \\
\text { ing process; } \\
\text { General perception that many member states } \\
\text { do not second their best staff to the mission; } \\
\text { Expectation management (the missions raised } \\
\text { high expectations, which could not be fulfilled); } \\
\text { Planning process is still too long and reaction } \\
\text { time is too slow to address new challenges; } \\
\text { Lack of political interest and commitment by } \\
\text { EU member states; } \\
\text { CSDP framework is not designed for big, com- } \\
\text { plex and long-term missions such as EULEX; } \\
\text { The mission is declared as a neutral party, } \\
\text { while on the other hand its goals are to support } \\
\text { local authorities in building state institutions, } \\
\text { which is contradictory; } \\
\text { Lack of understanding between Brussels level, } \\
\text { member states level and field level. }\end{array}$ & $\begin{array}{l}\text { Challenges: } \\
\text { - } \quad \text { Deployment phase: Quite lengthy; } \\
\text { The operation suffers from a lack of clear end- } \\
\text { state or exit/transition strategy; } \\
\text { Lacks of official and clear time-limited bench- } \\
\text { marks; } \\
\text { The "political realities" and the member states' } \\
\text { role are crucial and a showstopper for planning } \\
\text { process and execution; } \\
\text { - Short deployments of international staff not } \\
\text { contributing well to the efficiency of the work- } \\
\text { ing process; } \\
\text { General perception that many member states } \\
\text { do not second their best staff to the operation } \\
\text { and secondment is many timer perceived as a } \\
\text { training opportunity; } \\
\text { Reduced number of troops and especially the } \\
\text { current low number of liaison and observation } \\
\text { teams (LOT) compromise the ability to react } \\
\text { and respond in a timely manner to a potential } \\
\text { deterioration of the SASE in BiH; } \\
\text { Minor role in the strategic reform process } \\
\text { compared to NATO; } \\
\text { NATO's planning process perceived as more } \\
\text { efficient; } \\
\text { Current mandate perceived as reflecting mem- } \\
\text { ber states inability to define 'where to go. }\end{array}$ \\
\hline
\end{tabular}

Table 1: Planning Successes and Challenges in EULEX and EUFOR Althea

The CSDP missions and operations have been envisaged as a rather short-term response to a crisis but trends in the Western Balkans indicate they are used as relatively long-term post-conflict institution-building instruments, complementing other EU instruments. This is creating discrepancies between the strategic framework in which the interven- 
tions are planned and their implementation. It also highlights the importance of planning capacity, which has significant influence on the implementation of missions and operations. ${ }^{132}$ Despite many changes in the planning structures of CSDP, the planning process is still regarded as too slow. The lessons learnt from the Western Balkans might have also contributed to the fact that CSDP interventions deployed afterwards are much smaller in scale and their mandates less ambitious. Some EU representatives would even say that 'the EU is simply not made for CSDP' and that 'mistakes from EULEX with its justice component should never be repeated anywhere else. ${ }^{133}$ Research often analyses CSDP missions as projects, many times minimising their political nature, whereas they actually are 'political missions with technical mandates' and their deployment already sends 'a strong political signal.' ${ }^{\prime 34}$

Both missions in the Western Balkans are projecting EU's ambitions for the region, which became clearer in the new European Commission's Strategy for the Western Balkans in February 2018. ${ }^{135}$ EUFOR Althea's deployment enabled the EU to experiment with its military capabilities in a relatively safe risk-free environment with low costs. EULEX proved to be an especially complex case from the planning perspective since several political and legal obstacles hindered the mission planning. Relatively long planning processes followed in both cases, resulting in an eventual settlement for a compromise solution that was acceptable to all EU member states, the international community and conflicting parties. While compromises enabled the missions to be deployed eventually, they also lead to certain limitations, raising the question of balancing the political considerations and on-the-ground needs in the mission planning. ${ }^{136}$

The timeframe of planning the operation in $\mathrm{BiH}$ was not critical since the military problem had largely ceased to exist by the time EUFOR Althea took over its tasks from SFOR. Notwithstanding the political divisions related to CFSP and in the face of institutional opposition from some quarters (initially the Council and the Commission), ${ }^{137}$ EUFOR Althea was launched at a time of momentum for ESDP. No rapid deployment was deemed necessary and force generation did not present a challenge for the Union. Furthermore, the operation was not very demanding in terms of planning, since it has been carried out with recourse to NATO assets and capabilities under the Berlin Plus arrangements. The reaction and planning process of CSDP civilian missions is still relatively long. It often takes a lot of time to reach a political consensus within the EU and as Michael E. Smith

132 Boštjančič Pulko, Pejič and Muherina 2016.

133 IECEU Roundtable of experts 2016.

134 Deane 2017.

135 European Commission 2018.

136 Grilj and Zupančič 2016.

137 Flessenkemper and Helly 2013. 
argues, the non-executive missions would be much more effective under European Commission's leadership. ${ }^{138}$

Access to NATO planning assets, structures and capabilities under the "Berlin Plus" arrangements contributed to a smooth and relatively simple transition from SFOR. In the case of EULEX, the EUPT had been pointed out as a positive practice, despite the fact that results of the planning were adapted when the mission was eventually deployed in order to fit the political context. Issues from the operational planning level like human resources planning and the limited capability of the mission to effectively fulfil its executive role are even more obvious than the noted strategic considerations. Prolonged decisionmaking process, as in the case of EULEX, often results in compromises that do not necessarily reflect the actual needs of the host countries. ${ }^{139}$

Evident parts to be included in order to improve both missions' planning process are the standardization of pre-deployment training, definition of common EU-best practices and adapted durations of staff deployments. Despite the fact that deployment and initial planning were successful, the EU has failed to define and agree on an end state in both missions.

The 'political realities' and member states' role are crucial factors and CSDP missions are positioned very low on the political agendas of the member states, especially the Ministries of Foreign Affairs 'do not know what is in it for them, while the situation is better in the case of Ministries of Defence. ${ }^{140}$ This is reflected in many respects, including in the reluctances of the member states to second their best staff to these missions. Reduced number of troops due to withdrawing nations from EUFOR Althea results in low number of LOTs, which compromises the ability to react and respond in a timely manner to a potential worsening of the SASE in BiH. In EUFOR Althea's case national caveats have certainly been a challenge to the operational planning since evaluation criteria for the operational tasks have been discussed and drafted at the OHQ level since 2005, but the CSDP operation still lacks official and clear time-limited benchmarks. Lack of coordination or planning guidance exercised from strategic/political level toward operational level is an evident inadequacy. EUFOR Althea had good initial planning capacity but certain gaps manifest in the operational capacity, like the lack of human intelligence (HUMINT) capability, which hinders efficient and effective intelligence-gathering.

CSDP planning framework has evolved substantially during the years, it is complicated and encompasses certain structural challenges in order to make it a truly functional instrument, adequate for longer lasting and complex engagements. The findings of this paper indicate that if the EU wants to efficiently plan and conduct complex, long-term civilian and military CSDP interventions, then the mandates, structures and general ap-

\footnotetext{
138 Smith 2017.

139 Interviews no. 36, no. 34, no. 39, and no. 24.

140 Porzio 2017.
} 
proach of the EU should be adapted accordingly. This is of particular importance in the light of the new EU Global Strategy, stating that CSDP "must become" more responsive and effective. ${ }^{141}$ 


\section{References}

Bertin, Thomas. 2008. 'The EU Military Operation in Bosnia' in European Security and Defence Policy: An Implementation Perspective, edited by Michael Merlingen and Rasa Ostrauskaite, London: Routledge, 61-77.

Boštjančič Pulko, Ivana, Nina Pejič, and Meliha Muherina. 2016. "Analysing the Effectiveness of EUFOR Althea Operation in Bosnia and Herzegovina”. European Perspectives - Journal on European Perspectives of the Western Balkans. 8(2): 87-116. Accessed 15 April 2017. Available at https://www.cep.si/wp-content/uploads/2017/07/2016-8-2.pdf.

Boštjančič Pulko, Ivana, Johanna Suhonen and Kari Sianio. 2017. "Assessing the Planning and Implementation of the EU Missions and Operations: Case Study of EUFOR Althea in Bosnia And Herzegovina". Contemporary Military Challenges. September 2017-19/nr. 3: 61 - 80 .

Council of the European Union. 2004a. "Concept for the EU Military Operation in Bosnia and Herzegovina - Operation ALTHEA”. Accessed 15 December 2016. Available via: http://register.consilium.europa.eu/doc/srv?l=EN\&f=ST\%20 12576\%20 2004\%20INIT.

Council of the European Union. 2004b. "Council Decision 2004/803/ CFSP of 25 November 2004 on the launching of the European Union military operation in Bosnia and Herzegovina". Accessed 15 December 2016. Available at http://eur-lex.europa. eu/legal-content/EN/TXT/ HTML/?uri=CELEX:32004D0803(01)\&from=EN.

Council of the European Union. 2006. "Joint Action 2006/304/CFSP On the establishment of an EU Planning Team (EUPT Kosovo) ”. Accessed 25 July 2016. Available at: http://www.europarl.europa.eu/meetdocs/2004_2009/documents/dv/joint_action_kosovo_april06_/joint_action_kosovo_april06_en.pdf.

Council of the European Union. 2008a. "Declaration on the European Union Rule of Law Mission in Kosovo, EULEX Kosovo. Council document 2008/124/CFSP, Brussels 4 February 2008". Accessed 15 April 2016. Available at: http://www.eulexkosovo. eu/eul/repository/docs/WEJointActionEULEX_EN.pdf .

Council of the European Union. 2008b. "Council Joint Action Resolution 2008/124/ CFSP of 4 February 2008 on the European Union Rule of Law Mission in Kosovo, EULEX Kosovo".

Council of the European Union. 2010. Council Conclusions on Bosnia and Herzegovina. 5686/10. 
Council of the European Union. 2011. "Council Conclusions on CSDP-FAC 1 December 2011. Document 17991/1". Accessed 20 August 2017. Available at http://register.consilium.europa.eu/doc/srv?l=EN\&f=ST\%2017991\%202011\%20INIT.

European Council. 2013. "Conclusions of the European Council (19/20 December 2013)”. Accessed 20 February 2018. Available at http://data.consilium.europa.eu/doc/ document/ST-217-2013-INIT/en/pdf.

Council of the European Union. 2015. "EULEX Kosovo: mandate extended, budget approved. [Press release]”. Accessed 31 October 2016. Available at: http://www.consilium.europa.eu/sl/ press/press-releases/2016/06/14-eulex-kosovo-budget/.

Council of the European Union. 2017. "Concept Note: Operational Planning and Conduct Capabilities for CSDP Missions and Operations". Foreign Affairs Council, 6 March 2017.

Council of European Union Secretariat. 2015. "EU military operation in Bosnia and Herzegovina (Operation EUFOR Althea)”. Accessed 13 December 2016. Available at: http://eeas.europa.eu/archives/csdp/missions-and-operations/ althea-bih/pdf/factsheet_eufor_althea_en.pdf.

Cierco Teresa. and Liliana Reis. 2014. "EULEX's Impact on the Rule of Law in Kosovo”. Revista de Ciencia Politica: 33 (3): 645-663.

Deane, Kenneth. 2017. Statement at the conference '20 years of the Republic of Slovenia's participation in international operations and missions', 2 October 2017, Brdo pri Kranju, Slovenia.

de Kermabon, Yves. 2014. "Crisis Management Procedures" in Handbook for decision makers- The common security and defence policy of the European Union: 43-47.

De Munter, Andre. 2016. "Fact Sheets on the European Union - the Western Balkans”. Accessed 14 October 2016. Available at: http://www.europarl.europa.eu/ atyourservice/en/displayFtu.html?ftuId=FTU_6.5.2.html.

Douglas, Alexander. 2006. "Letter from Rt Hon Douglas Alexander MP, Minister for Europe, Foreign and Commonwealth Office to the Chairman". Accessed May 15, 2016. Available at: http://www.publications.parliament.uk/pa/ld200607/ldselect/ ldeucom/187/187119.htm.

Directorate-General For External Policies Of The Union. 2012. "CSDP Missions and Operations: Lessons Learned Processes”. Accessed 17 August 2016. Available at: http://www.tepsa.eu/download/CSDP\%20Missions\%20and\%20 Operations-\%20Lessons\%20Learned\%20Processes\%20(DG-\%20 External\%20Policies).pdf. 
EUFOR Althea. “About EUFOR”. Accessed 23 May 2016. Available at http://www. euforbih.org/eufor/index.php/about-eufor/background.

European External Action Service. 2016a“About CSDP - the Berlin Plus agreement”. Accessed 26 May 2016. Available at http://eeas.europa.eu/csdp/about-csdp/berlin/ index_en.htm.

European External Action Service. 2016b. "Shaping of a Common Security and Defence Policy”. Accessed 15 December 2016. Available via: https://eeas.europa.eu/ topics/ common-security-and-defence-policy-csdp/5388/shaping-of-acommonsecurity-and-defence-policy-_en.

European External Action Service. 2018. "Military and civilian missions and operations”. Accessed 10 March 2018. Available at https://eeas.europa.eu/topics/militaryand-civilian-missions-and-operations/430/military-and-civilian-missions-and-operations_en.

European Commission. 2018. "A credible enlargement perspective for and enhanced EU engagement with the Western Balkans". Acessed 10.03.2018. Available at https:// ec.europa.eu/commission/sites/beta-political/files/communication-credible-enlargement-perspective-western-balkans_en.pdf.

European Commission. 2018. Neighbourhood - Enlargement. Accessed 10 March 2018. Available at https://ec.europa.eu/neighbourhood-enlargement/countries/ detailed-country-information/.

European Union. 1992. Treaty on European Union, Treaty of Maastricht, signed 7 February 1992 in Maastricht, in force from 1 November 1993.

European Union. 1997. Treaty of Amsterdam, amending the Treaty on European Union, the Treaties establishing the European Communities and certain related acts, as signed on 2 October 1997 in Amsterdam, in force from 1 May 1999.

European Union. 1998. Saint-Malo Declaration, signed on 4 December 1998 in Saint-Malo.

European Union. 2007. Treaty of Lisbon, amending the Treaty on European Union and the Treaty Establishing the European Community, 13 December 2007, 2007/C $306 / 01$.

European Union Staff Group. 2016. "Basic brief of 7 January 2016: Operation Althea, from NATO”. Accessed 22 May 2016. Available at athttp://www.aco.nato.int/ page39511625.aspx. 
European Union Staff Group. 2016.“Operation ALTHEA OHQ in Shape”. Accessed 23 May 2016. Available at http://www.consilium.europa.eu/uedocs/cms_data/docs/ missionPress/files/100608\%20Shape\%20\%20EUFOR\%20Althea\%20OHQ\%20-\%20 how\%20it\%20works.pdf.

Flessenkemper, Tobias and Damien Helly. 2013.“Ten Years After: Lessons from the EUPM in Bosnia and Herzegovina 2002-2012". Paris: EU Institute for Security Studies, 9 .

Gourlay, Catriona. 2006. "Partners Apart: Enhancing Cooperation between Civil Society and EU Civilian Crisis Management in the framework of ESDP”. Accessed 16 December 2016. Available at: http://www.eplo.org/documents/Partners\%20Apart. pdf.

Grilj, Blaž and Rok Zupančič. 2016. "Assessing the Planning and Implementation of the EU Rule of Law Missions: Case Study of EULEX Kosovo". Journal European Perspectives. Volume 8 (2): 62-85.

Guttry, Andrea de. 2007. “The European Union Rule of Law Mission in Kosovo: Remarks on its Legality and its Relations with UNMIK." Diritto e Politichedell'UnioneEuropea, 3: 147-169. Accessed 24 June 2016. http://www.cdg-lab. dirpolis.sssup.it/files/2012/10/The-European-Union-Rule-of-Law-Mission-in-Kosovo-Remarks-on-its-Legality-and-its-Relations-With-UNMIK.pdf.

Hazelzet, Hadewych. 2013. “The added value of CSDP operations”. Accessed 14 October 2016. Available at: http://www.iss.europa. eu/uploads/media/Brief_31.pdf.

IECEU Roundtable discussion of experts. 2016. Conducted on 24 May 2016, Jable Castle, Slovenia.

Jacque, Jean-Paul. 2015. "Review of the EULEX Kosovo mission's implementation of the mandate with a particular focus on the handling of recent allegations". Accessed 12 April 2016. Available at: http://eeas.europa.eu/statementseeas/docs/150331_ jacque-report_en.pdf.

Jeluišič, Ljubica. 2016. “Research of Peace Missions and Operations”. European Perspectives - Journal on European perspectives of the Western Balkans. 8 (2): 11-13. Accessed 10 February 2018. Available at https://www.cep.si/wp-content/uploads/2017/07/2016-8-2.pdf.

Juncos, Ana. 2013/2015. EU Foreign and Security Policy in Bosnia: The Politics of Coherence and Effectivness. Manchester: Manchester Universty Press. 
Keohane, Daniel. 2009. 'The European Union Military Operation in Bosnia and Herzegovina (Althea)', in European Security and Defence Policy: The First 10 Years (19992009), edited by Giovanni Grevi, Damien Helly, and Daniel Keohane, Paris: EUISS.

Keukeleire, Stephen. and Robert Thiers R. 2010. "EULEX Kosovo: Walking a Thin Line, Aiming for the Rule of Law". The European Union and Peacebuilding.

Kim, Julie. 2006. "Bosnia and the European Union Military Force (EUFOR): PostNATO Peacekeeping”. 5 December 2006. Washington: The Library of Congress. Accessed 14 December 2016. Available at: http://www.dtic.mil/dtic/tr/fulltext/u2/ a464684.pdf.

Knauer, Jannik. 2011. „EUFOR Althea: Appraisal and Future Perspectives of the EU's Former Flagship Operation in Bosnia and Herzegovina”.

Knezović, Sandro. 2005. "Scanning EUFOR - Operation ALTHEA and a possible Croatia's role in it”. Croatian International Relations Review 11 (40): 125-32.

EUFOR Althea. 2016. "Liaison and observation teams in EUFOR”. Accessed 22 May 2016. Available at http://www.euforbih.org/eufor/index.php/eufor-elements/liaisonand-observation-teams.

Llaudes, Salvador and Francisco Sanchez Andrada. 2015. "EULEX: a mission in need of reform and with no end in sight”. Accessed 30 October 2016. Available at: http:// www.realinstitutoelcano.org/wps/portal/web/rielcano_en/ contenido?WCM_GLOBAL_CONTEXT=/elcano/elcano_in/zonas_in/ ari41-2015-llaudes-sanchezandradaeulex-mission-need-reform-noend-in-sight.

Mattelaer, Alexander. 2010. “The CSDP Mission Planning Process of the European Union: Innovations and Shortfalls". Understanding the Role of Bureaucracy in the European Security and Defence Policy, European Integration online Papers (EIoP), Special Issue 1, Vol. 14, http://eiop.or.at/eiop/texte/2010-009a.htm.

Mattelaer, Alexander. 2014."Who is in Charge? Natural Friction in the CSDP Decision-Making Process". Handbook for Decision Makers, the Common Security and Defence Policy of the European Union: 48-52. Accessed August 15, 2017. Available at https://eeas.europa.eu/sites/eeas/files/esdc_-_handbook-for-decision-makers.pdf.

Mekri, Maria. 2016. "IECEU deliverable D1.5 IECEU Conceptual Framework”. Accessed 13 June 2017. Available at http://www.ieceu-project.com/?page_id=2978.

Palm, Trineke. 2017. The changing character of EUFOR Althea: power politics or learning? Accessed 15 December 2017. 
Available at https://www.tandfonline.com/doi/full/10.1080/09557571.2016.1256947.

Papadimitriou, Dimitri and Petar Petrov. 2012. "Whose Rule, Whose Law? Contested statehood, External Leverage and the European Union's Rule of Law mission in Kosovo". Journal of Common Market studies 50 (5): 746-763.

Penksa, Susan. 2010. "Security Governance, complex peace support operations and the blurring of civil-military tasks". Rethinking Security Governance: 39-62.

Pietz, Tobias. 2017. “ZIF Policy Brief. September 2017”. Accessed 28 September 2017. Available at: http://www.zifberlin.org/fileadmin/uploads/analyse/dokumente/veroeffentlichungen/ZIF_Policy_Briefing_Pietz_GSVP_Sept_2017_EN.pdf.

Porzio, Georgio. 2017. Statement at "Joint Final Conference of WOSCAP E IECEU Research Projects: "Effectiveness and Inclusivity of EU Peacebuilding and Conflict Prevention". 8 November 2017, Brussels.

Recchia, Stefano. 2007. "EU Military Operation in Bosnia and Herzegovina, European Force in Bosnia and Herzegovina-EUFOR Mission".

Rehrl, Jochen and Hans-Berhnardt Weisserth. 2010. "Common Security and Defence Policy of the EU Handbook”. Accessed 20 May 2016. Available at: https://www.consilium.europa.eu/uedocs/cmsUpload/csdp_handbook_web.pdf.

Rehrl, Jochen. 2014. "Handbook for Decision Makers, the Common Security and Defence Policy of the European Union“. Accessed 15 August 2017. Available at: https:// eeas.europa.eu/sites/eeas/files/esdc_-_handbook-for-decision-makers.pdf.

Smith, Michael E. 2017. Statement given at the Belgrade Security Forum, during panel “The EU as a Global Crisis Manager”. 11 October 2017, Belgrade.

Suhonnen, Johana, and Kari Sainio. 2016. “D2.3of the IECEU Project, 2016”. Deliverable is based on data collection and interviews conducted by R. Zupančič, J.Suhonen, K. Sainio, E. Norvanto, J. Salonen, I. Boštjančič Pulko, M. Muherina and B. Udovič.

de Wet, Erika. 2009. “The Governance Of Kosovo: Security Council Resolution 1244 and the Establishment And Functioning of Eulex". The American Journal of International Law, 103/1: 83-97.

Zupančič, Rok. "D2.3 of the IECEU Project”. Deliverable is based on data collection and interviews conducted by R. Zupančič, J.Suhonen, K. Sainio, E. Norvanto, J. Salonen, I. Boštjančič Pulko, M. Muherina and B. Udovič. 
Zupančič, Rok. 2015. Kosovo: laboratorij preprečevanja oboroženih konfliktov, pokonfliktne obnove in izgradnje države”. Brno: V. Klemm.

\section{Interviews}

Interview no. 1, 2016. Interview with a EULEX official. 8 March 2016.

Interview no. 3, 2016. Interview with a Kosovo Ministry of Public Administration official. 7 March 2016.

Interview no. 4, 2016. Interview with an EU official. 30 March, 2016.

Interview no. 5, 2016. Interview with an EUSR official. 10 March 2016.

Interview no. 8, 2016. Interview with a EULEX official. 8 March 2016.

Interview no. 9, 2016. Interview with a EULEX official. 8 March 2016.

Interview no. 10, 2016. Interview with an EUSR official. 10 March 2016.

Interview no. 11, 2016. Interview with a EULEX official. 8 March 2016.

Interview no. 13, 2016. Interview with a Kosovo customs official. 11 March 2016.

Interview no. 15, 2016. Interview with a Kosovo police official. 10 March 2016.

Interview no. 16, 2016. Interview with a EULEX official. 11 March 2016.

Interview no. 18, 2016. Interview with a Kosovo Ministry of European Integration official. 10 March 2016.

Interview no. 19, 2016. Interview with a Kosovo NGO representative. 11 March 2016.

Interview no. 20, 2016. Interview with a EULEX official. 8 March 2016.

Interview no. 21 (2016). Interview with EEAS official, 28 January 2016.

Interview no. 22 (2016). Interview with former EUMS officer, 26 January 2016.

Interview no. 23 (2016). Interview with former EUFOR Althea officer, 28 January 2016. 
Interview no. 24 (2016). Interview with EUSG officer, 28 January 2016.

Interview no. 25 (2016). Interview with EUSG officer, 28 January 2016.

Interview no. 28 (2016). Interview with EUSG officer, 28 January 2016.

Interview no. 29. 2015. Interview with EEAS official, 16 July 2015.

Interview no. 31 (2016). Interview with former EUFOR Althea officer, 25 January 2016.

Interview no. 32 (2016). Interview with former EUFOR Althea officer, 25 January 2016.

Interview no. 33 (2016). Interview with former EUFOR Althea officer, 25 February 2016.

Interview no. 34 (2016). Interview with EUFOR Althea officer, 29 February 2016.

Interview no. 35 (2016). Interview with EUFOR Althea officer, 2 March 2016.

Interview no. 40 (2016). Interview with EUFOR Althea officer, 4 March 2016.

Interview no. 41 (2016). Interview with EUFOR Althea officer, 4 March 2016.

Interview no. 44 (2016). Interview with former EUFOR Althea officer, 9 March 2016.

Interview no. 46 (2016). Interview with EUFOR Althea officer, 14 March 2016.

Interview no. 47 (2016). Interview with EUFOR Althea officer, 20 March 2016.

Interview no. 52 (2016). Interview with representative of BiH MOD, 5 April 2016.

Interview no. 65 (2016). Interview with Official from Finish Ministry of Defence, 7 July 2015.

Interview no. 67 (2016). Interview with official from Ministry of Foreign Affairs of BiH, 3 March 2016.

Interview no. 68 (2015). Interview with official from International Centre for Migration Policy Development, former Althea official, 8 December 2015. 